\title{
A RARE CASE OF ACARDIAC TWIN
}

\author{
R. Padmaja1, Ch. Nirmala²
}

\section{HOW TO CITE THIS ARTICLE:}

R. Padmaja, Ch. Nirmala. "A Rare Case of Acardiac Twin". Journal of Evolution of Medical and Dental Sciences 2015; Vol. 4, Issue 11, February 05; Page: 1867-1870, DOI: 10.14260/jemds/2015/267

ABSTRACT: Fetus Acardiacus is a very rare manifestation of twin gestation. This happens due to TRAP sequence. That is Twin reversed arterial perfusion. In this case an amorphous mass was seen on a routine antenatal scan and followed as there was a live twin also. The case report highlights the importance of careful scanning and follow up of twin gestation.

KEYWORDS: TRAP Sequence, Discordant growth, Death of one twin, a large mass may obstruct labour.

CASE REPORT: A 28 yr old 2nd gravida with a live Fch 2 yrs old presented herself for an Antenatal scan at Govt Victoria Hospital Visakhapatnam. She had conceived in Lactational Amenorrhea and so her last menstrual period was not known. Her Marital life was 5 yrs and her Menstrual history was regular.

She had a full term normal vaginal delivery at a Government hospital.

Ultrasound scan showed A live fetus corresponding to 28 wks period of gestation. Placenta was Fundal, Grade 2, Anterior. A thin intertwin membrane was seen. In addition an amorphous mass of size $10 * 12 \mathrm{~cm}$ was also seen, without cardiac activity. Bony tissue was seen within the mass. There was also Hydramnios. A presumptive diagnosis of acardiac twin was made and she was sent for expert opinion scan which showed -Diamniotic Monochorionic twin gestation. Gestational age of $1^{\text {st }}$ twin was 28 wks 5 days Twin 2 Deformed - No evidence of fetal cranium, trunk and limbs. No fetal cardiac activity. Moderate size soft tissue density lesion with osseous structures suggestive of intra uterine demise of fetal monster. Polyhydramnios present. AFI -23.

ON EXAMINATION: Patient was pale with Haemoglobin of $7.7 \%$ and a PCV of $21 \%$.Blood pressure was 140/100 mmhg, Lungs and Cardiovascular system appeared normal. Height of Uterus was 28 wks. Her other lab parameters were as follows;

Blood group and Rh type 0+,Bleeding time $2 \mathrm{~min} 18 \mathrm{sec}$, Clotting time $3 \mathrm{~min} 45 \mathrm{sec}$, Total count 10300 cells/mm3, DC - Neutrophils 80\%,Lymphocytes 18\%,Platelets 3.2 lacs/mm3, ESR -34 $\mathrm{mm} / 1^{\text {st }}$ hour, HIV and HbsAg Non-Reactive, Urine Albumin 1+.

CASE MANAGEMENT: In view of gestational hypertension and intrauterine demise of 1 twin, a decision to induce labour was taken.1 unit of compatible o+ Blood was transfused prior to induction. Induction was started with $25 \mathrm{mcg}$ Misoprostol repeated $6^{\text {th }}$ hourly. She delivered Vaginally. A live male child with Apgar 8-10 was born and was admitted to IPCU In view of low birth weight of $1.1 \mathrm{~kg}$. There was also an amorphous mass attached to the placenta. She was discharged on the $5^{\text {th }}$ post natal day and was then lost to follow up.

DISCUSSION: Acardiac fetus was $1^{\text {st }}$ described by Gruenwald in 1942 and is also known as Acephalus Chorioangiopagus Parasiticus. Incidence 1 in 35000, 1\% in monochorionic twins. It is a consequence of TRAP (twin reversed arterial perfusion). It is characterized by- Discordant development, usually 


\section{CASE REPORT}

occurs In monozygotic, monochorionic, and also monoamniotic twins (unlike here) and also in triplets.(1)

It is thought to result from direct artery to artery anastomoses in the placenta.Circulation for both is maintained by 1 twin only as second twin has NO heart. When arterial pressure in 1 twin (donor) exceeds that of the other, blood flow is reversed in perfused twin.(2)

The lower limbs of the $2^{\text {nd }}$ twin get de oxygenated blood and develop only partially whereas the head and upper half are absent. This is because the used arterial blood reaching the recipient twin preferentially goes to the iliac vessels and thus perfuses only the lower half of the body.(3)

By the time blood reaches upper half of body most of whatever little oxygen is left will already have been extracted leading to poor development of upper body structure.

There are types like myelacephalus, acephalus and amorphus. Hydramnios and cystic hygroma are common.(4)

Robie and co in 1989 stated that frequently the acardiac twin has chromosomal anomalies but the PUMP twin usually has a normal karyotype and such anomalous fetuses have a higher rate of intra uterine demise. In dichorionic twins this may take the form of a vanishing twin.(called gross reduction.(5)

Diagnosis of acardiacus is normally made in $2^{\text {nd }}$ trimester. It is differentiated from IUFD by the presence of fetal movements and typical retrograde perfusion.(1)

Absence of an identifiable heart and multiple reduction anomalies in 1 twin is diagnostic. Can be detected on sonography as early as $10 \mathrm{wks}$.

Pump twin is at risk of high output heart failure because of extracardiac work load.Mortality is $50 \%$ for pump twin and $100 \%$ for acardiac twin.Cause of death is usually heart failure and extreme prematurity.

MANAGEMENT: WHENEVER INRAUTERINE DEMISE IS SUSPECTED IN MONOCHORIONIC TWINS on a $1^{\text {st }}$ trimester scan, DD of or DEVELOPMENT OF T R A P should be kept in mind and follow up scans arranged.(1)

Here, in view of gestational hypertension and intrauterine demise of 1 twin,a decision to induce labour was taken.

Quintero and associates have suggested in utero interruption of vascular communications between donor and recipient twin. They have ligated umbilical cord of 11 acardiac twins at 21 weeks period of gestation.(1)

Tsao and co reported 12 out of 13 donor twins surviving when a radio ablation needle was used to cauterize umbilical vessels and terminate blood flow to recipient twins under ultrasound guidance at $18-24$ wks POG.(1)

Hydramnios can be controlled by serial amniocentesis,pharmacological intervention with Indomethacin is risky.(2)

Consideration should be given to size of parasitic acardiac twin which may grow to several times the size of co twin and obstruct labour. 


\section{CASE REPORT}

\section{REFERENCES:}

1. Philip J Steer, Weiner C, Gonik B. - High Risk Pregnancy -Management options -4th ed. $419-422$, 2011.

2. Cunningham G, Macdonald P, Norman F Gant, Kenneth J Leveno- Williams obstetrics $20^{\text {th }}$ ed. 1997;861.

3. Arias F. A PRACTICAL GUIDE to high risk pregnancy and delivery,pp 293 -310, 2000.

4. Gopalan S, Jain V. Mudaliar and Menons Clinical Obstetrics -10 th ed. $184-185,2005$.

5. Oxorn H. - Human Labor and Birth $5^{\text {th }}$ ed. $324-325,2000$.
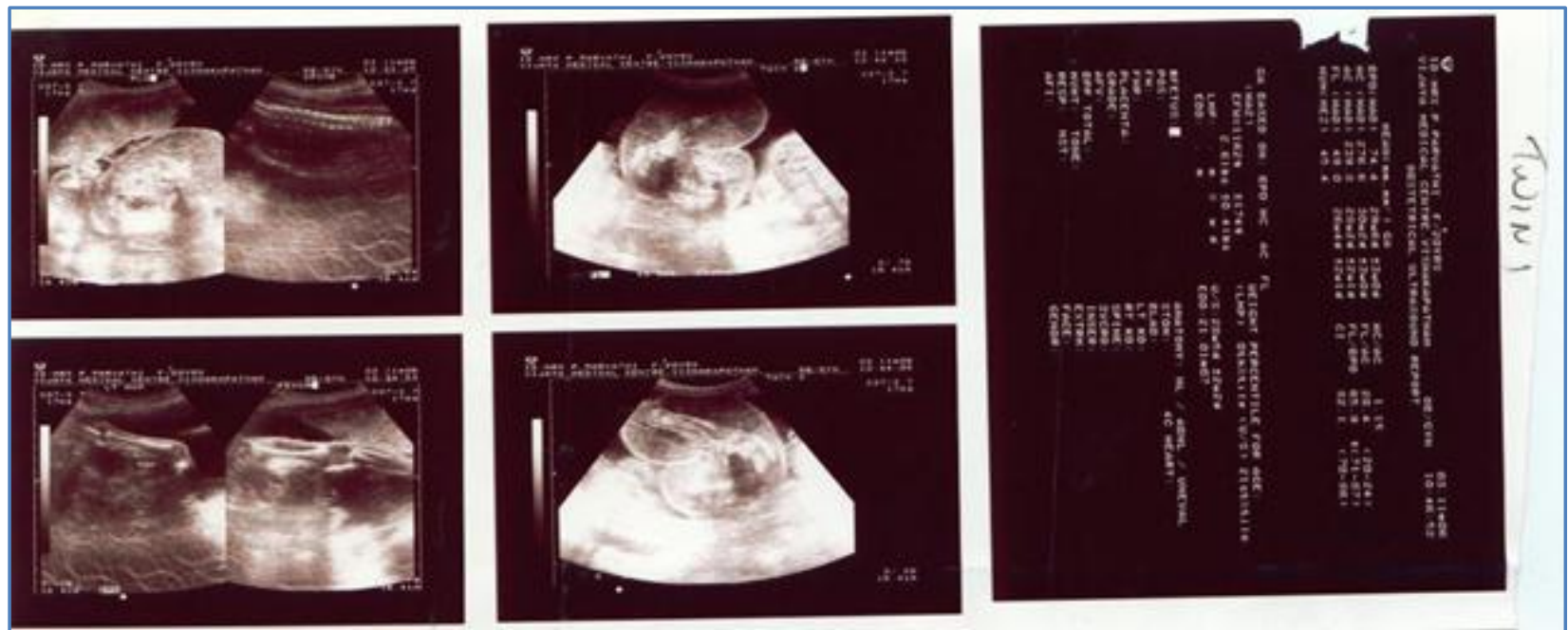

\section{Figure 1}

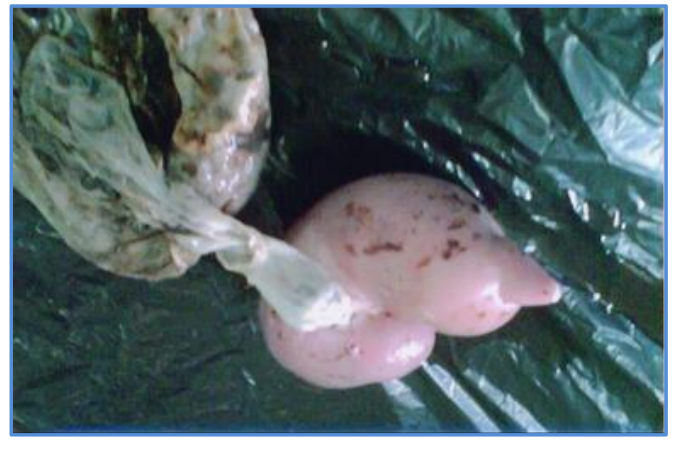

Figure 2

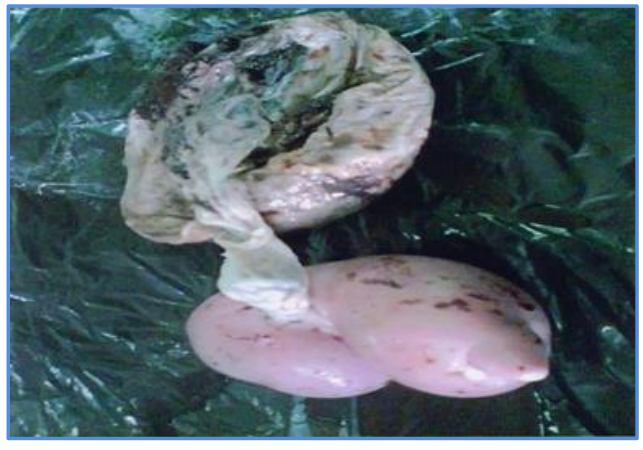

Figure 3 


\section{CASE REPORT}

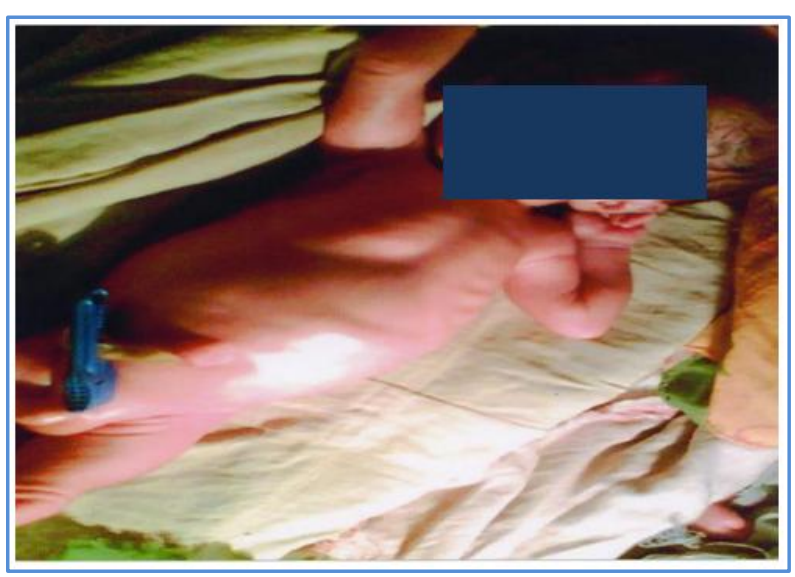

\section{Figure 4}

\section{AUTHORS:}

1. R. Padmaja

2. Ch. Nirmala

\section{PARTICULARS OF CONTRIBUTORS:}

1. Assistant Professor, Department of Obstetrics \& Gynaecology, Andhra Medical College.

2. Assistant Professor, Department of Obstetrics \& Gynaecology, Andhra Medical College.

\section{NAME ADDRESS EMAIL ID OF THE} CORRESPONDING AUTHOR:

Dr. R. Padmaja,

\section{\# 15-9-4/17,}

Flat No. 101, Sea Scape Apartments,

Krishna Nagar, Maharanipeta,

Visakhapatnam-530002.

E-mail: rajupadmaja1971@gmail.com

Date of Submission: 23/01/2015.

Date of Peer Review: 24/01/2015.

Date of Acceptance: 28/01/2015.

Date of Publishing: 05/02/2015. 